\title{
When the litigation winner becomes the loser: undeserving claimants and mitigation of damages in libel claims
}

\author{
Alexandros K. Antoniou
}

\begin{abstract}
The article assesses how the English courts have compensated defamed claimants who had misconducted themselves before action or during the course of litigation. It demonstrates that in recent years judges appear to have liberalised their approach to accepting evidence in mitigation of libel damages and allowed claimants' disreputable conduct to restrict the level of awards almost to a vanishing point. The article argues that this emerging approach does not cohere with that adopted in other branches of tort, where claimants' misbehaviour does not affect the level of general damages awarded, and carries with it the risk of undermining the vindicatory policy of libel law.
\end{abstract}

Keywords: libel, damages, mitigation, dishonest claimants

\section{Corresponding author details:}

Alexandros K. Antoniou

University of Essex

School of Law

Colchester C04 3SQ

Tel: +44 (0)1206 872565

Email: a.antoniou@essex.ac.uk

\section{Acknowledgements:}

I am immensely grateful to Prof Lorna Woods for her valuable comments on earlier versions of the manuscript. Any errors are my own responsibility and should not tarnish the reputation of this esteemed professional. 
This is an Accepted Manuscript of an article that will be published by Taylor \& Francis in the Journal of Media Law and it will be available at the following permanent link:

https://doi.org/10.1080/17577632.2019.1574468.

\section{Introduction}

Courts have often been confronted with publishers' misbehaviour and have compensated claimants, occasionally quite generously, where certain features of a case have exacerbated the injury caused by a defamatory statement and aggravated the damages. ${ }^{1}$ While there is a substantial body of authority emphasising the impact of the reprehensibility of defendants' conduct on the size of libel awards, the effect of claimants' behaviour on the assessment of damages has been the subject of the courts' enquiry less frequently. The claimants' bad reputation and provocation can mitigate damages, and are covered by some authority, ${ }^{2}$ but the precise effect of a claimant's misconduct on the award has not been settled by judicial determination and has received little academic consideration. This article aims to address this gap.

More specifically, this article is concerned with defamation cases where the court concluded in its findings after proof that a claimant who succeeded on the issue of liability behaved before action or during the course of litigation in a dishonest or disreputable manner. This includes conduct which was not necessarily connected causally to the publication of the libel complained of, but was seen by judges as culpable to a degree that warranted a reduction of damages to a minimum level (e.g. lies given in evidence). ${ }^{3}$ The article argues that such an approach does not cohere with that adopted in other branches of tort, where claimants' misbehaviour does not affect the level of general damages awarded, and carries with it the risk of eroding the vindicatory goal of libel law. This concern is equally profound when considered in light of the new contours of defamation claims. As explained later, the effect of the 'serious harm' standard enacted in the Defamation Act 2013 is to 'stiffen the common threshold test'. ${ }^{4}$ Claimants who have advanced a sufficient case on serious reputational harm, by reference to the seriousness of the imputation conveyed by the words used, can reasonably be expected to have a strong sense of worry over the adverse consequences of serious defamatory imputations. Important questions thus arise as to whether derisory awards alone are sufficient to eradicate, or at least minimise, the unfavourable impressions created by the severity of the offending statements.

The article first explores the interplay between the size of an award and the vindicatory function of libel damages, which is a significant but comparatively neglected aspect within modern tort law scholarship, despite being deeply ingrained in the internal structure of defamation. ${ }^{5}$ As will be discussed, this vindicatory aspect concerns the attitude of others towards the claimant and requires that the award is of sufficient magnitude to signal to the world that the allegation complained of is unfounded. A judge may find it necessary to inflate the final award in order to satisfy this vindicatory element. But, where the claimant's conduct is open to criticism by the court, a judge may also explicitly make a lower award because his or her reasoned judgment

\footnotetext{
${ }_{1}^{1}$ Sutcliffe v Pressdram Ltd [1991] 1 QB 153, 184 (Nourse LJ); John v MGN Ltd [1997] QB 586, 616; John Clement Carpenter Gatley, Gatley on Libel and Slander (12th ed, Sweet \& Maxwell 2017) 9.18.

2 Scott v Sampson (1882) 8 QBD 491.

${ }^{3}$ For a discussion of cases where it is established as a result of preliminary proof, or it transpires during proof, that litigants have set out to put the fairness of the trial in jeopardy by fraudulent means, see The Rt Hon Lord Reed, 'Lies, Damned Lies: Abuse of Process and the Dishonest Litigant', lecture delivered at the University of Edinburgh in October 2012 as the 5th Annual Lecture at the Centre for Commercial Law $<$ https://www.supremecourt.uk/docs/speech-121026.pdf> accessed 28 May 2018

${ }^{4}$ Gatley (n 1) 1.1.

${ }^{5}$ Jason Varuhas, "The Concept of "Vindication" in the Law of Torts: Rights, Interests and Damages' (2014) 34(2) OJLS 253.
} 
This is an Accepted Manuscript of an article that will be published by Taylor \& Francis in the Journal of Media Law and it will be available at the following permanent link:

https://doi.org/10.1080/17577632.2019.1574468.

offered vindication. ${ }^{6}$ Adopting a doctrinal approach involving the interpretative, qualitative analysis of primary legal texts and secondary literature, ${ }^{7}$ the article also evaluates settled and emerging principles concerning the claimant's conduct as a mitigating factor in assessing damages.

With this essential context established, the article then moves on to consider what insights can be gleaned from the position of claimants who had had their reputation disparaged and claimed substantial damages yet received, partly because of their perceived dishonesty in the past or disreputable conduct of their case, only negligible awards. In such cases, vindication is predominantly found in the judges' reasons. However, such an outcome does not sit well together with the libel courts' recognition that vindication is very much closely aligned to the size of the award and the public perceptions that result from it. There may thus, understandably, be some scepticism about the extent to which nominal damages, coupled with a ruling containing express elements of vindication, can solely be relied upon to redress the interference with a claimant's reputational interests. In considering this issue, the discussion juxtaposes the libel courts' approach with that adopted by the courts in other tortious actions with respect to decreasing the level of a dishonest claimant's award. The Supreme Court has, in particular, rejected arguments in favour of reducing the general damages for a genuine personal injury on the ground that a claim had been supported by dishonest devices, and held that the claimant was entitled to damages in an ascertained sum, irrespective of his conduct. 8 But, as the analysis demonstrates, the law of defamation appears to be moving towards a different direction.

It is suggested that libel courts' increasingly unhesitant and robustly critical evaluation of claimants' behaviour constitutes evidence that English judges have begun working towards the imposition of a merits-based approach, akin to the 'clean hands' ${ }^{9}$ doctrine applicable to equity cases, thereby requiring a claimant to be 'deserving' before and during the course of litigation. However, an implication of this peculiar dissociation of the tort of defamation from other branches of tort law may be a form of unhealthy dissonance, whereby the purported vindicatory purpose ascribed to minimal or derisory awards is rather faint, with some measure of solace possibly derived only from the court's final judgment on the merits. Concerns as to whether claimants may ultimately leave the court under-vindicated and perhaps unfairly compensated are no less acute following the statutory imposition of a threshold of seriousness in the 2013 Act.

Importantly, in an age of rapidly evolving communication technologies, which provide new tools for widespread dissemination and retrieval of information, the role and effect of vindication becomes crucial, particularly where the defendant has not offered to make a public apology. The old cliché that 'today's newspaper pages are tomorrow's fish and chip wrapping' no longer holds true. The long-term effect of libel is stronger now and can be described as being analogous to a tattoo; ${ }^{10}$ it is extremely difficult to get rid of and even if one tries to, there is still a shadow left. Thus, the libel courts' emerging practice raises the difficult issue of how far a judge sitting alone

\footnotetext{
${ }^{6}$ Barron and Anr v Vines [2016] EWHC 1226, [21] (Warby J); Zahawi v Press TV [2017] EWHC 1010, [15] (Master McCloud).

${ }^{7}$ Terry Hutchinson and Nigel Duncan, 'Defining and describing what we do: doctrinal legal research' (2012) 17(1) Deakin Law Review 83.

${ }^{8}$ Fairclough Homes Ltd $v$ Summers [2012] UKSC 26 (27 June 2012).

9 John McGhee, Snell's Equity (33rd ed, Sweet \& Maxwell 2017) 5-010; see also Grobbelaar v News Group Newspapers Ltd and Anor [2002] UKHL 40, [90] (Lord Scott).

${ }^{10}$ Clarke (t/a Elumina Iberica UK) v Bain [2008] EWHC 2636, [55] (Tugendhat J).
} 
This is an Accepted Manuscript of an article that will be published by Taylor \& Francis in the Journal of Media Law and it will be available at the following permanent link:

https://doi.org/10.1080/17577632.2019.1574468.

should reduce an underserving claimant's award on the grounds of the vindicatory effect of their carefully reasoned judgment. The next section provides the background against which these matters need to be considered.

\section{Vindication and libel damages in the post 2013 Defamation Act climate}

There is no general power in defamation law to order a defendant to publish an apology or suitable correction and therefore damages tend to be the primary remedy in such claims.11 Damages compensating a claimant for loss of reputation are at large in relation to both libel and slander,12 namely they are not limited to the pecuniary loss that can be specifically proved and calculated. ${ }^{13}$ The advent of the Defamation Act 2013 has not displaced the common law presumption of damage to reputation, ${ }^{14}$ and thus an award of damages can be made on the basis of presumed loss. Moreover, an award must serve three intertwined and synergistic purposes: it is required to compensate a claimant for unquantifiable damage to his reputation flowing from the libel; vindicate his good name; and provide an element of solatium to the claimant for the 'distress, hurt and humiliation' caused by the publication at issue. ${ }^{15}$ All three of these purposes appear to reflect the significance attached to the value of an individual's reputation as an aspect of his or her property, honour and dignity. ${ }^{16}$

Substantial defamation damages are often awarded by way of giving effect to the protected interests. ${ }^{17}$ Since the latest libel reforms which resulted in the passage of the Defamation Act 2013 , damages have ranged from $£ 18,000$ to $£ 200,000.18$ The size of an award is dependent on the relative extent of the interference with a claimant's reputational interests and not necessarily on its specific consequential effects on a particular claimant. ${ }^{19}$ Defamation damages must be

\footnotetext{
${ }^{11}$ A final injunction preventing further publication of the defamatory statement may accompany an award of damages. Interim injunctions ordered before publication are more controversial remedies. The rule against prior restraints is strengthened by s 12 of the HRA 1998 concerning interim reliefs.

12 Christian Witting, Street on Torts (14th ed, OUP 2015) 584.

${ }^{13}$ Rookes v Barnard [1964] AC 1129, 1221 (Lord Devlin).

${ }^{14}$ Lachaux v Independent Print Ltd \& Evening Standard Ltd [2017] EWCA Civ 1334, [58] and [82] (Davis LJ).

${ }^{15}$ John (n 1) 607E-F (Sir Thomas Bingham MR); Cairns v Modi; KC v MGN Ltd [2012] EWCA Civ 1382, [21] (Judge LCJ).

${ }^{16}$ Eric Barendt, 'What is the Point of Libel Law?' (1999) 52(1) Current Legal Problems 110, 115; Broome v Cassell \& Co Ltd [1972] AC 1027, 1070 (Lord Hailsham); see further Robert Post, "The Social Foundations of Defamation Law: Reputation and the Constitution' (1986) 74(3) California Law Review 691.

${ }^{17}$ Rantzen v Mirror Group Newspapers (1986) Ltd and Ors [1994] QB 670, 696 (Neill LJ); Hourani v Thompson and Ors [2017] EWHC 432, [237] (Warby J).

${ }^{18}$ See Zahawi (n 6) (£200,000); Rahman v ARY Network Ltd [2016] EWHC 3110 ( $\left.£ 185,000\right) ;$ Al-Amoudi v Kifle and Anr [2013] EWHC 293 (£180,000); Cruddas v Calvert, Blake and Times Newspapers Ltd [2013] EWHC 2298 ( $€ 180,000$ but reduced to $£ 50,000$ on appeal); Harrath v Stand for Peace Ltd and Anr [2017] EWHC $653(£ 140,000)$. Comparatively lower awards were made in: Sooben $v$ Badal [2017] EWHC 2638 (70,000); Hourani (n 17) (80,000); Flood v Times Newspapers Ltd [2013] EWHC 4075 (£60,000); Garcia v Associated Newspapers Ltd [2014] EWHC 3137 (£45,000); Barron v Collins [2017] EWHC 162 (£54,000); Lisle-Mainwaring v Associated Newspapers Ltd and Anr [2017] EWHC 543 (£54,000); Monroe v Hopkins [2017] EWHC 433 (£24,000); Kadir \& Barakah UK Ltd v Channel S Television [2014] EWHC 2305 $(£ 20,000) ;$ Barron (n 6) (£40,000); Oyston and Ors v Ragozzino [2015] EWHC $3232(£ 20,000)$; and Woodward v Grice [2017] EWHC 1292 (£18,000).

${ }^{19}$ Varuhas (n 5) 283. However, characteristics specific to a claimant, like the subjective impact of the libel on them, may be considered; see Cruddas v Adams [2013] EWHC 145, [48] - [49] (Eady J). In this case, the defamatory allegations that Mr Cruddas was 'a criminal who deserved to be behind bars' were found to
} 
This is an Accepted Manuscript of an article that will be published by Taylor \& Francis in the Journal of Media Law and it will be available at the following permanent link:

https://doi.org/10.1080/17577632.2019.1574468.

enough to provide reasonable compensation but because an award represents an interference with Convention rights, it must be proportionate to the injury suffered by a claimant and no more than necessary to 're-establish his reputation'. ${ }^{20}$ Several factors are considered by libel courts in assessing the seriousness of the interference. The gravity of the defamatory imputation is a major determinant of damages: 'the more closely it touches the plaintiff's personal integrity, professional reputation, honour, courage, loyalty and the core attributes of his personality, the more serious it is likely to be'.21 The extent of the publication is also another relevant factor: 'a libel published to millions has a greater potential to cause damage than a libel published to a handful of people'. ${ }^{22}$ In a landscape of modern technology and communication systems, the court will also consider the tendency of damaging statements to percolate and 'go viral' via the Internet more quickly than ever before. ${ }^{23}$ Damages for injury to feelings may be included in a general award and can be significant, as a court must take into consideration what the claimant 'thinks other people are thinking of him'.24

In a nutshell, it is well-established that a court's conclusion must ensure that a claimant obtains adequate vindication of the baselessness of the published allegations as well as suitable compensation for the injury caused to his reputation and feelings both by the libel and by conduct after publication (e.g. the wounding way in which the proceedings were conducted on behalf of the defendant may aggravate damages). Even though vindication is recognised as an express purpose of defamation damages, its meaning seems to have most often been accepted by libel courts as self-explanatory. Essentially, its gist can be captured as repairing the harm caused to a claimant's perceived status and the esteem in which he or she is held by others. ${ }^{25}$

There is some lack of definite conviction as to which aspects of defamation proceedings effect vindication. ${ }^{26}$ A claimant may obtain some measure of vindication from a reasoned judgment, giving the judge's conclusions and detailed reasons for reaching them. In particular, the Court of Appeal articulated in Purnell 27 a rather moderate position on this matter, holding that in principle 'a prior narrative judgment rejecting a defence of justification and so holding the libel to be established is capable of providing some vindication of a claimant's reputation'. ${ }^{28}$ The degree of vindication will, however, almost invariably depend on the circumstances. For instance, a claimant can secure some vindication from a reasoned judgment following a hotly litigated trial (possibly accompanied by a fair amount of attendant publicity) in which the defendant's witnesses were thoroughly discredited and a firm finding in his or her favour was arrived at. Nevertheless, the court recognised in Purnell that the effect of such an earlier judgment vis-à-vis vindication would most likely be 'marginal'29 and that there would also be cases where a

have gravely damaged his personal reputation which was 'intimately linked' to that of his business; see also Michael Jones (ed), Clerk and Lindsell on Torts (22nd ed, Sweet \& Maxwell 2017) 22-226.

${ }^{20}$ Rantzen (n 17) 696 (Neill LJ).

${ }^{21}$ John (n 1) 607 (Sir Thomas Bingham MR).

22 Ibid; see also Gathercole v Miall (1846) 15 M \& W 319, 331 (Pollock CB).

${ }^{23}$ Cairns (n 15) [27] (Judge LCJ).

${ }^{24}$ Broome (n 16) 1125 (Lord Diplock).

25 David Rolph, Reputation, Celebrity and Defamation Law (Routledge 2016) 44.

${ }^{26}$ David Rolph, 'Vindicating Reputation and Privacy' in Andrew Kenyon (ed), Comparative Defamation and Privacy Law (CUP 2016) 296.

27 Purnell v Business Magazine Ltd [2007] EWCA Civ 744.

28 Ibid [29] (Laws LJ, with whom the other two members of the court agreed).

${ }^{29} \mathrm{Ibid}$. 
This is an Accepted Manuscript of an article that will be published by Taylor \& Francis in the Journal of Media Law and it will be available at the following permanent link:

https://doi.org/10.1080/17577632.2019.1574468.

judgment would provide 'no or no significant or reckonable vindication', ${ }^{30}$ for example, where judgment was granted in default and there was no contested decision on the merits. ${ }^{31}$ It is eminently plausible that the terms of a judgment cannot sensibly be viewed as a substitute for a sum which can be pointed to as affording appropriate vindication. Thus, a prior reasoned judgment in the claimant's favour does not negate any requirement to have vindication reflected in the damages.

\section{Vindication in compensatory (general) damages}

Although vindication is identified as a purpose of damages distinct from that of compensation, the English courts' preference is to treat it as an intrinsic part of compensation for libel. Judges have frequently emphasised the imperative need to vindicate the claimant's reputation through an effective remedy, citing Lord Radcliffe words in Dingle that 'a libel action is fundamentally an action to vindicate a man's reputation on some point as to which he has been falsely defamed, and the damages awarded have to be regarded as the demonstrative mark of that vindication'.32 In Uren v John Fairfax \& Sons Pty Ltd, Windeyer J spoke of compensatory damages as a vindication of the claimant to the public. His observations are particularly instructive:

\footnotetext{
a man defamed does not get compensation for his damaged reputation. He gets damages because he was injured in his reputation, that is simply because he was publicly defamed. For this reason, compensation by damages operates in two ways - as a vindication of the plaintiff to the public and as consolation to him for a wrong done. Compensation is here a solatium rather than a monetary recompense for harm measurable in money. ${ }^{33}$
}

Windeyer J's words were approved by the House of Lords in Broome $v$ Cassell ${ }^{34}$ and the emphasis on vindication has become more pronounced since then. 'If the award fails to achieve vindication it fails properly to compensate', 35 Warby J observed in Sloutsker. In Metropolitan International Schools, a $£ 50,000$ award for an Internet libel alleging that the claimant's distance learning courses were a scam was principally for 'vindication'. ${ }^{36}$ The vindicatory aspect of damages was in Farrall 'very much in play', ${ }^{37}$ especially in the absence of a retraction or apology, following the online publication of an unwarranted slur which attacked a young solicitor's professional competency and probity. Moreover, although the claim form in Harrath indicated that the claimant did not expect to recover more than $£ 10,000$ over false terrorism allegations posted on a website with a readership in the hundreds or low thousands, Sir David Eady assessed damages at $£ 140,000$ to ensure that 'no doubt [was left] in the mind of a reasonable onlooker of the claimant's entitlement to vindication'.38 And in ZAM $v C F W$, Tugendhat J remarked that 'the primary object of libel actions is to vindicate a claimant's reputation; not to recover damages'. ${ }^{39}$

\footnotetext{
30 Ibid [30].

${ }^{31}$ Al-Amoudi v Kifle [2011] EWHC 2037, [38] (HHJ Richard Parkes).

32 Dingle v Associated Newspapers [1964] AC 371, 396 (Lord Radcliffe).

33 (1966) 117 CLR 118, 151 (emphasis in the original).

34 Broome (n 16) 1071 (Lord Hailsham).

35 Sloutsker v Romanova (Rev 1) [2015] EWHC 2053, [77].

36 Metropolitan International Schools Ltd v Designtechnica Corp [2010] EWHC 2411, [35] (Tugendhat J);

37 Farrall v Kordowski [2011] EWHC 2140 (Lloyd Jones J).

38 Harrath (n 18) [23].

39 [2013] EWHC 662, [72].
} 
This is an Accepted Manuscript of an article that will be published by Taylor \& Francis in the Journal of Media Law and it will be available at the following permanent link:

https://doi.org/10.1080/17577632.2019.1574468.

Nevertheless, an award of libel damages is part of the process which seeks to reverse the effect of the infringement with the claimant's reputational interests. As Barker astutely observes,

since reputational damage actually consists in a deleterious change in the public perception of a person, its remediation entails an equivalent change for the better in that perception and monetary sums are calculated symbolically with this objective in mind. 40

The vindicatory function of the award and its size are tightly - but also intricately - interwoven. The chances of the courts interfering with a publisher's editorial freedom and ordering retractions or apologies are likely to be extremely remote, so the importance attached to the size of an award becomes even more apparent: in order to fully redress the injury to the claimant's reputation, the level of damages must be sufficient to apprise the community that the defendant has been 'publicly proclaimed to have inflicted a serious injury'.41

The vindicatory aspect may be underlined by increasing an award to the top of the range which is deemed suitable under the circumstances. ${ }^{42}$ The notional ceiling for compensatory damages in libel proceedings, which is arrived at by reference to the top figure for pain, suffering and loss of amenity in personal injury claims, ${ }^{43}$ is currently accepted to be of the order of $£ 300,000$. Such awards are though reserved for the gravest cases involving for instance widespread imputations of murder or terrorism. ${ }^{44}$ Introducing, however, an element of vindication in libel damages may be thought to risk transforming the award into an unmerited windfall for the claimant. Indeed, the size of defamation awards was in the past a source of concern. 45 There was suspicion that the jury made, under the mask of vindicating a claimant's reputation, excessively high awards which were, in essence, vindictive penalties against media defendants. However, following the abolition of the presumption in favour of a jury trial, ${ }^{46}$ the assessment of damages will rarely be left for the jury's consideration. It is now a matter for the judge sitting alone, and a consequence of this is that a more realistic and 'more or less coherent' 47 framework of awards has been built up.

40 Kit Barker, 'Private and Public: The Mixed Concept of Vindication in Torts and Private Law' in Stephen Pitel, Jason Neyers and Erika Chamberlain (eds), Tort Law: Challenging Orthodoxy (Hart Publishing, 2013) 76.

${ }^{41}$ The Gleaner Co Ltd v Abrahams [2003] UKPC 55, [55] (Lord Hoffman).

42 John (n 1) 607E-F (Sir Thomas Bingham MR); Jameel v Wall Street Journal Europe SPRL [2006] UKHL

44, [24] (Lord Bingham of Cornhill); McCarey v Associated Newspapers Ltd and Ors (No 2) [1965] 2 QB 86, 105 (Pearson LJ).

43 Barron v Collins (n 18), [26].

${ }^{44}$ Rai v Bholowasia [2015] EWHC 382, [179] (HHJ Parkes QC); Barron v Collins (n 18) [26]; Harrath (n 18); Lisle-Mainwaring (n 18) [62]. The ceiling figure rises with inflation but its increase since 2012, when Tugendhat J noted in Cairns (n 15) [25] and ZAM (n 39) [65] that it was about $£ 275,000$, is also a consequence of Simmons v Castle [2012] EWCA Civ 1039, in which the Court of Appeal set guidelines on the level of general damages for all types of non-pecuniary loss in all civil actions, at 10 per cent higher with effect from 1 April 2013.

${ }^{45}$ See John (n 1) 608, where Lord Bingham famously described the jurors as being in a position of 'sheep loosed on an unfenced common, with no shepherd', lacking an instinctive sense of where to pitch their award. The jury's discretion in assessing damages is not, however, unfettered. The Courts and Legal Services Act 1990, s 8 empowers the Court of Appeal to level down what it may consider to be extravagant damages and substitute a 'proper award' without being invited to so by the parties; see John (n 1), McCartan Turkington Breen v Times Newspapers Ltd [2001] 2 AC 277 and Kiam v MGN Ltd [2002] EWCA Civ 43, in which the Court of Appeal provided further guidance on when and how this power should be exercised.

46 Defamation Act 2013, s 11.

${ }^{47}$ Barron v Vines (n 6) [81] (Warby J). 
This is an Accepted Manuscript of an article that will be published by Taylor \& Francis in the Journal of Media Law and it will be available at the following permanent link:

https://doi.org/10.1080/17577632.2019.1574468.

Notwithstanding the centrality of vindication to the stated purposes of defamation damages, its relationship to the award remains relatively obscure. Although compensatory damages can be inflated to vindicate a claimant's 'good name' and restore their social standing, it is uncertain how the need for vindication precisely affects the assessment of an award and how the vindicatory effect on third parties can be measured. An illustration of this point can be found in the recent case of Pirtek, ${ }^{48}$ where the claimant company, which provides hydraulic hose replacement services to the industry, brought a libel claim against a former franchisee who carried out a campaign online (and via social media postings) disparaging the company's products and services. Warby J held that the allegations tended to cause serious financial loss to the claimant 49 and awarded the maximum permissible under the Defamation Act 1996,50 explaining that the gravity of the statements at issue called for a 'substantial vindicatory award'.51 And in Flood, which involved an article claiming that there were strong grounds to believe that a police officer was dishonest and corrupt, it was felt that The Times' persistence in the allegation and failure to inform its readers of the outcome of the investigation which exonerated the claimant, represented a 'particular need'52 for vindication requiring a 'proper'53 sum by way of damages. However, it is difficult to find any additional evidence in the judgments that would help clarify the distinct weight attached to vindication as a factor in the assessment of damages. It is not unreasonable to suppose that it is hard to disentangle vindication from the other two interlocking aims of libel damages but some degree of uncertainty over its relationship with the award may be removed, if vindication is regarded predominantly as 'a check on the award' assessed by reference to solace and reparation: it reminds the court to adjust the level of the overall award, so that it is 'sufficient to impress on the community that the defamation was wrongful and has been effectively remedied'. 54

\section{Vindication in exemplary, aggravated and nominal damages}

Compensatory awards, which are calculated - to the extent that money can do so - to put the claimant in the same position he or she would have been, absent the defendant's tortious conduct, ${ }^{55}$ may be supplemented by aggravated or exemplary damages. Nominal damages can also be awarded where a claimant is technically successful in establishing that his or her legal right has been infringed but cannot show any factual loss or real (recognised) harm as a result of the libellous publication. These three types of damages (aggravated, exemplary, nominal) vary in their relative vindicatory force and the priority they place on 'making good' the claimant's name and place in public.

Exemplary damages are available only in limited cases and where the sum awarded by way of compensation is not sufficient to 'punish for outrageous conduct, to mark the jury's disapproval

\footnotetext{
48 Pirtek (UK) Ltd v Jackson [2017] EWHC 2834.

${ }^{49}$ Defamation Act 2013, s 1(2).

50 Defamation Act 1996, s 9(1)(c). Where the summary procedure under ss 8-10 of the Act applies, damages are capped at $€ 10,000$.

51 Pirtek (n 48) [75].

${ }^{52}$ Flood (n 18) [59] (Davies J).

53 Ibid.

${ }^{54}$ Normann Witzleb and Robyn Carroll, 'The role of vindication in torts damages' (2009) 17 Tort Law

Review 16, 35.

${ }^{55}$ Livingstone v The Rawyards Coal Company (1880) 5 App Cas 25, 39 (Lord Blackburn).
} 
This is an Accepted Manuscript of an article that will be published by Taylor \& Francis in the Journal of Media Law and it will be available at the following permanent link:

https://doi.org/10.1080/17577632.2019.1574468.

of such conduct, and to deter a repetition'.56 In the context of libel, a court must be satisfied that the defendant did not believe in the truth of what he or she had published and had been motivated by 'a cynical calculation that publication was to his mercenary advantage'. 57 On a micro-level, exemplary damages may be deemed 'analogous to a criminal penalty', 58 but the underpinning policy of the law is to 'teach the defendant and others that "tort does not pay" by demonstrating what consequences the law inflicts rather than simply to make the defendant suffer an extra penalty for what he has done'.59 The fact that the civil law takes the exceptional step of punishing a defendant for the manner of their interference with a claimant's reputational interests reinforces the importance attached to these and further suggests that exemplary damages can also be seen as playing a vindicatory role on a macro-level. 60 The Crime and Courts Act 2013 now puts exemplary damages on a statutory footing and gives the courts a fairly wide discretion to make such awards, if claimed, where the defendant's conduct demonstrated 'a deliberate or reckless disregard of an outrageous nature for the claimant's rights'. ${ }^{61}$ However, publishers who were voluntarily signed up at the material time to an approved regulatory body under the postLeveson Royal Charter system enjoy a limited immunity from exemplary damages. ${ }^{62}$

General damages may be aggravated by the 'extraordinary'63 conduct of the defendant, their conduct of the case or their state of mind. A maliciously published libel, for example, is likely to be more hurtful than a libel which was erroneously published and expeditiously corrected. Aggravated damages can be recovered for 'injury to pride and dignity, and the consequence of humiliation'64 and as such they represent a more generous sum than a more moderate award which would typically be given to a claimant. ${ }^{65}$ For instance, Eady J awarded the claimant in Johnson $£ 70,000$ by way of compensatory and aggravated damages for libel, following a sustained attack upon him by the defendant through blogs and Twitter accounts. ${ }^{66}$ The Law Commission recommended as far back as 1997 that this head of damages should only be awarded to compensate for the mental distress sustained by a claimant as a result of the defendant's conduct and should not include a punitive element. ${ }^{67}$ This recommendation is now substantiated by the

\footnotetext{
56 Rookes (n 13) 1228 (Lord Devlin).

${ }^{57} \mathrm{John}$ (n 1 ) 587. In the last 50 years, the law concerning the award of exemplary damages has been considered in three cases by the House of Lords, i.e. Rookes (n 13), Broome (n 16), Kuddus v Chief Constable of Leicestershire Constabulary [2002] 2 AC 122, and in one case in the Supreme Court, i.e. $R$ (Lumba) v Secretary of State for the Home Department [2011] 2 WLR 671. Their facts are not relevant for present purposes.

${ }^{58}$ John (n 1) 607 (Sir Thomas Bingham MR). See, however, in Broome (n 16) 1086 Lord Reid's position on the 'highly anomalous' punitive practice of awarding exemplary damages in civil proceedings without clear legal basis for doing so.

${ }^{59}$ Broome (n 16) 1073 (Lord Hailsham).

60 Varuhas (n 5) 290.

${ }^{61}$ Crime and Courts Act 2013, s 34(6).

62 Ibid s 34(2).

63 Johnson v Steele and Ors [2014] EWHC B24, [12] (Eady J).

${ }^{64}$ The Right Honourable Lord Justice Leveson, An Inquiry into the Culture, Practices and Ethics of the Press, Volume IV (The Stationary Office 2012) 1510.

${ }^{65}$ For the relationship between aggravated damages and other types of damages, see Gatley (n 1) 9.21 and Mark Lunney, Donal Nolan and Ken Oliphant, Tort Law (6th ed, OUP 2017) 891 who draw attention to the overlap between aggravated and exemplary damages.

${ }^{66}$ Johnson (n 63).

${ }^{67}$ Law Commission, Aggravated, Exemplary and Restitutionary Damages (Law Com No 247, 1997) 183.
} 
This is an Accepted Manuscript of an article that will be published by Taylor \& Francis in the Journal of Media Law and it will be available at the following permanent link:

https://doi.org/10.1080/17577632.2019.1574468.

Crime and Courts Act 2013.68 Being conceptually separated from exemplary damages, by both their name and the pre-conditions of availability, aggravated damages appear to incorporate a modest vindicatory quality to the extent that they recognise the inescapable link between the defendant's contumelious motive or otherwise offensive conduct and the heightened sense of injury and grievance caused to the claimant and his self-esteem.

The classic exposition of the definition of nominal damages is found in The Mediana, where Lord Halsbury LC stated:

'Nominal damages' is a technical phrase which means that you have negatived anything like real damage, but that you are affirming by your nominal damages that there is an infraction of a legal right which, though it gives you no right to any real damages at all, yet gives you a right to the verdict or judgment because your legal right has been infringed. 69

Awards of this kind usually comprise a small amount ( $£ 20$ or less) and as such, it would be difficult to envisage that they are capable of serving as the best vehicle for reminding those interested that the libellous allegations complained of were without foundation. They are, however, seen as marking the existence of the right to reputation and its violation by the wrongdoer. ${ }^{70}$ Hence, they may be regarded as performing a relatively limited vindicatory function through their expressive capacity to determine the scope and reinforce the inherent value of the claimant's protected interests.

Historically, nominal damages were regarded as 'a mere peg on which to hang costs'. ${ }^{71}$ The rule of awarding costs in favour of the successful party denoted the rather deterministic notion that an award of even token damages in favour of that party represented the formal recognition of their success with respect to the application of the law at issue. However, a review of more recent authorities shows that a party obtaining an award of nominal damages will not necessarily be regarded as a successful party ${ }^{72}$ in light of the courts' powers and practice on costs. ${ }^{73}$ Sound policy reasons may justify to an extent this position: a general rule that nominal awards will normally carry a costs order in the claimant's favour may not be particularly welcome, because the lure of procuring costs may create a potential risk of unwarranted and opportunistic litigation.

Awards of a token sum are sometimes referred to as 'contemptuous damages'. ${ }^{74}$ In the words of Lord Esher MR in Whittaker, these are typically awarded '[...] if a libel were a trivial or ridiculous one, in respect of which the jury thought that an action ought not to have been brought'. ${ }^{75}$ In these situations, although a court may find that a claimant's interests have been unlawfully breached, it may refuse to exercise its discretion (from the damages being at large) in his or her favour and award the coin of the lowest denomination in current circulation (1p). This implies a sharp criticism and conveys the message that very little sympathy with the claimant is warranted. It is

\footnotetext{
68 Crime and Courts Act 2013, s 39.

69 Owners of the Steamship Mediana v Owners of the Lightship Comet Mediana [1900] AC 113, 116.

70 Lord Scott, 'Damages' (2007) 4 Lloyd's Maritime and Commercial Law Quarterly 465, 469; James

Edelman, Jason Varuhas and Simon Colton (eds), McGregor on Damages (20th ed, Sweet \& Maxwell 2017)

12-011; Varuhas (n 5) 275, 292.

71 Beaumont $v$ Greathead (1846) 2 CB 494, 499 (Maule J).

72 Hyde Park Residence Ltd v Yelland and Ors [1999] EMLR 654, 672 (Jacob J); Anglo Cyprian Trade

Agencies v Paphos Wine Industries [1951] 1 All ER 873.

73 Senior Courts Act 1981, s 51 and CPR 44.2(1), discussed later.

74 Baily v Truth and Sportsman Ltd (1938) 60 CLR 700, 708 (Latham CJ), 728 (McTiernan J).

75 Whittaker v Scarborough Post Newspaper Co [1896] 2 QB 148, 149.
} 
This is an Accepted Manuscript of an article that will be published by Taylor \& Francis in the Journal of Media Law and it will be available at the following permanent link:

https://doi.org/10.1080/17577632.2019.1574468.

therefore only rarely possible that such damages can achieve any sensible degree of vindication. The old authorities of Newstead ${ }^{76}$ and Pamplin, 77 where one farthing (now 0.1p) and one halfpenny were awarded respectively, are notable examples in this regard. Contemptuous damages are mainly used in defamation actions and the introduction of the new threshold of serious harm under s 1 of the Defamation Act 2013, which aims to discourage unmeritorious claims, means that such awards are likely to become scarcer. Having considered this essential framework, the analysis proceeds to examine the correlation between the parties' conduct and the award, focusing in particular on claimants who were found to have misconducted themselves.

\section{The importance of good conduct: the winner does not 'take it all'}

The size of a libel award can reflect the additional injury caused to a claimant's feelings by the defendant's acts or omissions from the point of the publication complained of up until the time of judgment, ${ }^{78}$ including for instance their refusal to acknowledge the falsity of the claims (up to the closing submissions), ${ }^{79}$ their conduct in contesting the action before and the trial, 80 and the persistence with which the defamatory allegations were advanced. ${ }^{81}$ For their part, defendants may seek to reduce the amount of damages from what might otherwise have been appropriate by invoking evidence of absence of malice, ${ }^{82}$ evidence that the claimant has already recovered damages over substantially the same allegations ${ }^{83}$ and that they made (or offered to make) an apology or offer of amends. A defence of partial justification (or truth) will not prevent the claimant from succeeding on the issue of liability, but it can be important with regard to the issue of damages. The extent of the reduction depends on how close the defendant has come to establishing the substantial truth of the allegation. ${ }^{84}$ A reduced sum may also be awarded, if evidence before the court demonstrates that the claimant's reputation is already so besmirched that the words complained of could not cause any further injury.

In light of the serious harm requirement under the 2013 Act, the claimant's reputation will be 'very much in play from the outset.' 85 This requirement was enacted in a legal context which recognised the principle of 'a real and substantial tort' established in Jameel 86 and a threshold of seriousness - phrased in terms of substantiality - expounded in Thornton. ${ }^{87}$ Building on the consideration given by the courts in these previous authorities to the question of what is sufficient to establish that a statement is defamatory, Parliament intended to 'raise the bar's8 by

\footnotetext{
76 Newstead v London Express Newspapers [1940] 1 KB 377 (CA).

77 Pamplin v Express Newspapers Ltd (No 2) [1988] 1 WLR 116 (CA).

78 John (n 1) 607-608 (Sir Thomas Bingham MR).

${ }^{79}$ Cruddas v Adams (n 19) [41] (Eady J).

80 See Cruddas v Calvert (n 18) [301] - [303], in which the cross-examination of the claimant and the defendant's conduct were found by the court to be 'offensive' to him.

81 Rahman (n 18) [106] (Eady J); Woodward (n 18).

82 Pearson v Lemaitre (1843) 5 M \& G 700, 719 (Tindal CJ).

83 Defamation Act 1952, s 12.

${ }^{84}$ Pamplin (n 77) 120 (Neill LJ).

85 Clerk and Lindsell on Torts (n 19) 22-239.

86 Jameel v Dow Jones \& Co [2005] EWCA Civ 75, [70] (Phillips LJ).

87 Thornton v Telegraph Media Group Ltd [2010] EWHC 1414, [86] (Tugendhat J).

88 Explanatory Notes to the Defamation Act 2013, para 11.
} 
This is an Accepted Manuscript of an article that will be published by Taylor \& Francis in the Journal of Media Law and it will be available at the following permanent link:

https://doi.org/10.1080/17577632.2019.1574468.

introducing a 'stricter test' 89 for bringing a defamation claim, so that trifling and undeserving claims are not permitted to proceed..$^{90}$ Although it is not entirely clear how much higher the bar is raised, the change from substantiality to seriousness did not mean, according to Davis LJ in Lachaux, that 'the labours of Parliament have produced a mouse':91 'On the contrary, [...] Parliament has in effect given statutory status to the decision in Thornton whilst at the same time raising the threshold from one of substantiality to one of seriousness'. ${ }^{92}$ 'Serious' in s 1 of the Act, Davis LJ observed, conveys something 'rather more weighty'93 than 'substantial', arguably corresponding to a 'Thornton Plus' standard. ${ }^{94}$ The common law presumption of damage is compatible with s 1 and has not been affected by the Defamation Act 2013. But, 'there is no presumption at law of serious damage in a libel case'. ${ }^{95}$ Accordingly, this must be proved, usually by an inferential case where an allegation has a serious defamatory meaning. ${ }^{96}$ Once this threshold is crossed, further evidence will be material to the quantum of damage, if liability is established.

The quantum of injury sustained reflects the principle that a claimant with an unsullied reputation is likely to suffer greater harm than a claimant of considerable notoriety. ${ }^{97}$ The 1882 case of Scott $v$ Sampson established that defendants are permitted to rely on general evidence of the claimant's ill-repute but specific acts of unrelated unsavoury misconduct which do not form part of a substantive defence, like truth, cannot be advanced in mitigation. 98 The law distinguishes between a claimant's actual reputation and instances in his or her life which ought to determine his or her reputation. ${ }^{99}$ It follows that damages cannot be reduced by demonstrating, for example, that a claimant would have a bad reputation, if his past conduct was known. ${ }^{100}$ Introducing such evidence could result in endless disputes and a disproportionate increase in costs. However, the courts have expressly sanctioned a deviation from this rule in respect of 'the raw material upon which bad reputation is built up',101 i.e. criminal convictions, provided that they are relevant to the words complained of and not temporally distant (in the sense that they have taken place within a relevant period so as to affect a claimant's current reputation).102

\footnotetext{
89 Joint Committee on the Draft Defamation Bill, Draft Defamation Bill (2010-12, HL 203, HC 930-I) [62]; Ministry of Justice, The Government's Response to the Report of the Joint Committee on the Draft Defamation Bill (Cm 8295, 2012) paras 8-10.

90 Lachaux (n 14) [43].

91 Ibid [78].

92 Ibid.

93 Ibid [44] (emphasis in the original).

94 At the time of writing (November 2018), the Supreme Court is considering the proper construction of s 1(1) of the 2013 Act and the extent to which the bar has been raised in Lachaux (Respondent) $v$ Independent Print Limited and Anr (Appellants) UKSC 2017/0175, against the Court of Appeal decision of Davis LJ, with whom MacFarlane and Sharp LJJ concurred, [2017] EWCA Civ 1334.

95 Lachaux (n 14) [72] and [82].

96 Ibid.

97 Scott (n 2) 503 (Cave J); Speidel v Plato Films Ltd and Ors [1960] 3 WLR 391, 396 (Devlin LJ).

$98 \operatorname{Scott}$ (n 2).

99 Speidel (n 97) 396 (Devlin LJ).

100 Lord Chancellor's Department (LCO 13/124), Report of Committee on Defamation (Cmnd 5909, 1975)

para 363; Clerk and Lindsell on Torts (n 19) 22-242.

101 Goody v Odhams Press Ltd [1964] 1 QB 333, 340 (Lord Denning MR); applied in King v Grundon [2012] EWHC 2719.

102 See, for example, the recent case of Oyston (n 18), where the High Court assessed damages in a defamation claim brought by the claimant football club, its chairman and its owner against a club
} 
This is an Accepted Manuscript of an article that will be published by Taylor \& Francis in the Journal of Media Law and it will be available at the following permanent link:

https://doi.org/10.1080/17577632.2019.1574468.

The boundaries between evidence of bad reputation and evidence of specific instances of misbehaviour are not always sharply defined. Despite previous calls for its abolition,103 Parliament chose not to relax the Scott principle, 104 partly on the grounds of a potential reverse 'chilling effect', i.e. that claimants would be deterred from pursuing a matter for fear that they would be exposed to further 'muck-raking' by the media. ${ }^{105}$ Nevertheless, the Court of Appeal controversially ruled in Burstein 106 that evidence of 'directly relevant background context' is admissible to be considered in mitigation, because it is closely pertinent to the damage which has allegedly been caused by the defamatory publication. The court's approach appears to have been influenced in part by the spirit of the then newly introduced Civil Procedure Rules, which require the court to 'deal with cases justly'.107 The parameters of the Burstein plea were clarified to some extent later in Turner, ${ }^{108}$ in which Moses LJ held that, for the purpose of mitigating damages, defendants' evidence should be 'directly relevant to a claimant's conduct or reputation in the particular sector to which the defamatory material relates'. ${ }^{109}$ In other words, the farther apart from the defamatory statement the subject matter of the proposed Burstein evidence is, the less likely it is to be admitted.

The fortification of the Burstein plea in Turner creates a flexible set of principles that have the potential to shield a claimant from unreasonable and unwarranted attacks to his or her reputation. It appears, however, that Turner calibrates the scales in favour of the defendant and leaves the claimant's interests dependent on the courts' overall discretion to determine on a caseby-case basis the degree to which evidence of the claimant's general reputation is connected to the subject matter of the defamatory statement. This may be justifiable to the extent that the court has a strong interest in enabling the most clear-sighted and unblinkered consideration of the claimant in its efforts to establish the blemishing impact of a libel.

The claimant's acts or omissions at the time of publication are material too. ${ }^{110}$ Libels which were published by the claimant and provoked the defamatory statement for which redress is claimed can mitigate damages. ${ }^{111}$ In Godfrey, the defendant, an Internet Service Provider, was granted leave to amend its defence to include evidence of newsgroup postings made by the claimant which were found by the court to be 'puerile, unseemly and provocative'112 and 'causally

supporter, who had made several postings on Internet websites containing allegations of a sexual nature against them and falsely alleging corrupt behaviour. The club's owner had been convicted of a rape and indecent assault in 1996. The judge noted that the defendant was not prohibited from making a reference to this aspect of the claimant's personal past and that damages had to be reduced because of the claimant's general bad reputation in relation to his sexual conduct.

103 Report of Committee on Defamation (n 100); Gwyneth Pitt, 'Report of the Committee on Defamation' (1976) 39(2) MLR 187.

104 Turner v News Group Newspapers Ltd and Anr [2006] EWCA Civ 540, [38] - [40].

105 Richard Caddell, 'Directly relevant background context' and defamation damages' (2006) 65(3)

CambLJ 493, 495.

106 Burstein v Times Newspapers Ltd [2001] 1 WLR 579.

107 CPR 1.1.

108 Turner (n 104).

109 Ibid [89]; see also Keene LJ's less simple construction in [56].

110 Dingle (n 32) 395 (Lord Radcliffe).

111 Watts v Fraser and Anr (1835) 174 ER 154, 155 (Lord Denman CJ); Kelly v Sherlock [1866] LR 1 QB

686, 698 (Blackburn J); Broome (n 16) 1071 (Lord Hailsham LC).

112 Godfrey v Demon Internet Ltd [1999] EWH 240, [15] (Morland J). 
This is an Accepted Manuscript of an article that will be published by Taylor \& Francis in the Journal of Media Law and it will be available at the following permanent link:

https://doi.org/10.1080/17577632.2019.1574468.

connected'113 to the libel complained of. Moreover, in Gorman, which concerned a libel contained in a mock press release, the Court of Appeal reduced a jury award of $£ 150,000$ to $£ 50,000$ partly because of the role played by the claimant herself in a long-standing 'bitter dispute' which had developed between 'two strong-minded individuals who were capable of expressing themselves with vigour'.114 In Trumm, where a train driver sought damages in relation to defamatory statements published about him by the general secretary of the driver's trade union, Tugendhat J halved the claimant's damages on the basis that he had initiated himself a 'slanging match'.115 The tone of his preceding website postings was 'unnecessarily provocative and offensive,'116 thereby triggering the publication of the allegations complained of.

Claimants may also find their damages affected by their position in relation to the resolution of the dispute. In Campbell v News Group Newspapers Ltd (No 2),117 the Court of Appeal allowed the appeal against a jury award over a News of the World article which alleged that the claimant was an active paedophile. It was found that there was partial, yet significant, justification in the form of 'a highly perverted interest in boys' 118 and that the claimant had dishonestly attempted to improve the outcome of the litigation itself. He had procured false testimony, made the most damaging'119 allegations of corruption and lying against the defendant's lawyers, and attacked the credibility of an innocent third party. Although the court accepted that the 'very serious'120 defamatory statements in the appellants' publication could not be fully justified, it felt that it would have been an 'affront to justice',121 had the claimant's own disreputable conduct been ignored in assessing damages. Consequently, it heavily reduced the original award from $£ 350,000$ to $£ 30,000$ to reflect the fact that the claimant had engaged in 'the grossest misconduct'122 up to and during the trial.

It appears therefore that the claimants' behaviour in the past and conduct of their case at trial emerge as weighty factors in assessing the appropriate amount of damages. Notwithstanding their success on liability, claimants' conduct can also lead to a dramatic reduction of an award, even to the tune of a nominal $€ 1$, which is occasionally accompanied by negative costs orders. ${ }^{123}$ Recent illustrations of the interplay between the claimant's misconduct and the resultant nominal damages in the context of libel raise questions about the extent to which claimants who recovered negligible awards can properly be regarded as successful and vindicated litigants. Joseph $v$ Spiller ${ }^{124}$ and FlyMeNow v Quick Air Jet ${ }^{125}$ are particularly noteworthy cases in this regard. An interesting but comparatively disregarded aspect of both judgments is the consideration of the vindicatory aspects of the awards made. FlyMeNow also provides the opportunity to explore the

\footnotetext{
113 Ibid [20] (Morland J).

114 Gorman v Mudd (CA, 15 October 1992) (see Russell LJ and Neill LJ in particular).

115 Trumm v Norman [2008] EWHC 116, [53] (Tugendhat J).

116 Ibid [52].

117 [2002] EWCA Civ 1143.

118 Ibid [31].

119 Ibid [119].

120 Ibid [21].

121 Ibid [33].

122 Ibid [115].

123 Senior Courts Act 1981, s 51 and CPR 44.2(1).

${ }^{124}$ Craig Joseph, Jason Joseph \& Anthony Raymond v Jason Spiller \& 1311 Events Ltd [2012] EWHC 2958 (26 October 2012).

125 FlyMeNow Ltd v Quick Air Jet GmbH [2016] EWHC 3197.
} 
This is an Accepted Manuscript of an article that will be published by Taylor \& Francis in the Journal of Media Law and it will be available at the following permanent link:

https://doi.org/10.1080/17577632.2019.1574468.

issues considered in this article from the corporate claimants' angle. Bodies trading for profit are required under s 1(2) of the Defamation 2013 Act to demonstrate that an imputation has caused or is likely to cause them 'serious financial loss' in order to meet the serious harm requirement. For instance, a loss of the ability to attract custom and generate revenue could be persuasive evidence of the adverse financial effects of the poisonous allegations. ${ }^{126}$ The date of the contested publication in FlyMeNow, i.e. 5 December 2013, meant that the new Act, which came into force in January 2014, did not apply. However, when viewed through the lens of the higher, 'serious harm' and 'serious financial loss' thresholds in the post-Defamation Act 2013 libel landscape, the concern arising from the possibility of judicial censure through nominal damages is considerably accentuated. It seems well arguable that the need for the unfavourable allegation to be contradicted in the public mind through a demonstrable mark of the wrong done becomes more pressing and the remedial role of vindication as a 'check on the award' even more pronounced.

The case in Joseph was brought by the three members of a Motown tribute band, known as The Gillettes, against an entertainment agency and its director, Mr Spiller, who secured work for them. The underlying business dispute, which was branded by Lord Philipps as a 'considerable storm in a teacup',127 emerged over a critical notice which the defendants posted on their website, questioning the band's trustworthiness and ability to abide by their contractual obligations. The case presents a rather long and complex litigation history. Before trial, the defendants successfully argued for the reinstatement of their defence of fair comment before the Supreme Court. ${ }^{28}$ At trial, although the claimants succeeded on the merits, Tugendhat J found that, following the publication of the words complained of, the first claimant, Craig Joseph, carried on 'a sophisticated deception' 129 of the court by deliberately advancing a false claim for special damages. It was accepted, in particular, that he misled the court and abused its process by knowingly putting forward, and relying on, a fabricated document in support of part of his claim for damages resulting from the cancellation of two bookings.130 The 'dishonest and untrustworthy'131 conduct of Mr Joseph in deceiving the court throughout the proceedings, including at trial, was deemed so serious that he could not be awarded any substantial damages. The musician eventually recovered only 'nominal' 132 damages, in the sum of $£ 0.01$. Although there was no suggestion that the second and third claimants had been 'dishonest', 133 they were jointly known as The Gillettes and their reputations were intimately linked to that of the first claimant,

126 The loss of one client for a small law firm with high value instructions has been held in Brett Wilson LLP v Person(s) Unknown [2015] EWHC 2628 to show a likelihood of serious financial loss, but what constitutes such a loss for a small privately-owned company is likely to be assessed differently in relation to a large public limited company.

127 Spiller and Anr v Joseph and Ors [2010] UKSC 53 (appeal from Joseph and Ors v Spiller and Anr [2009] EWCA Civ 1075).

128 This was the first libel case considered by the UK Supreme Court since its inception. The court was primarily concerned with the extent to which, if at all, the common law defence of fair comment requires that the comment identifies the matter to which it relates. The test applied by Lord Nicholls that 'the comment must explicitly or implicitly indicate, at least in general terms, the facts on which it is based' is now reflected in s 3(3) of the Defamation Act 2013.

129 Joseph (n 124) [155].

130 Ibid [177].

131 Ibid [166].

132 Ibid [184].

133 Ibid [181]. 
This is an Accepted Manuscript of an article that will be published by Taylor \& Francis in the Journal of Media Law and it will be available at the following permanent link:

https://doi.org/10.1080/17577632.2019.1574468.

who was acting on their behalf. As such, the remaining members of the musical act had to rely on the reasons for judgment as sufficient vindication of their reputation.

In FlyMeNow, an aircraft charter company registered in England claimed damages for libel against a German aviation company which provides private jets. The parties entered a contract for the provision of two air ambulance flights in July and August 2013. Both went on, but debts accrued due to the claimant's failure to make full payments of the charter fees before the flights. Whilst there were still outstanding payments, and after several attempts to collect them from the claimant in relation to these flights, the defendant circulated in December of the same year an email to the generic email addresses of 26 companies in the aviation industry. The email was sent internationally but the claim related only to the publication within England and Wales. The message was headed 'WARNING: Company you should not deal with! Pecuniary difficulties!'; its body stated that the claimant, who was clearly identified by their company name, address and website details, was a 'defaulting debtor' 134 and was 'obviously incapable to pay their outstanding amounts in total'.135 The natural and ordinary meaning of the words complained of went, in Warby J's view, so far as to suggest that FlyMeNow was insolvent. On the evidence, it was 'very largely' 136 true that it would be financially unsafe for any industry party to engage in business with FlyMeNow, but it was held that the defence of justification was not made out. The claimant's plea of malice failed but so did the defence of qualified privilege. The alternative defence of abuse of process was not established either. Accordingly, the claimant was entitled to judgment on liability.

Despite the above, it was decided that FlyMeNow was entitled to an award of minimal damages to the tune of $£ 10.137$ Scathing criticism of the claimant's attitudes in advancing their case and pursuing their claims permeated Warby J's judgment. The claimant's case was found 'confused and confusing'138 and their position on payment terms vague and inconsistent. ${ }^{139}$ Moreover, the claimant's bank balances showed that, although the amounts deposited were at times sufficient to discharge their contractual payment obligations towards the defendant, money was paid out to unrelated third parties, whose demands were prioritised. As Warby J put it, 'the claimant was "robbing Peter to pay Paul".140 He made plain his severe disapproval of the claimant's 'delaying [payment] tactics'. ${ }^{141}$ These seemingly resulted from their rigid determination to follow internal policies which were aimed at hedging exchange-rate risk but were inconsistent with any contractual rights. In the judge's view, the claimant behaved 'dishonestly' 142 in implementing such an approach. They repeatedly attempted to appease the defendant with lies ${ }^{143}$ and constant promises of payment which were broken. ${ }^{144}$ The witness for the claimant, a director of the

\footnotetext{
134 FlyMeNow (n 125) [65].

135 Ibid [55].

136 FlyMeNow (n 125) [132].

137 Ibid [130].

138 Ibid [74].

139 Ibid [75] - [76].

140 Ibid [67].

141 Ibid [96].

142 Ibid [94].

143 Ibid [127].

${ }^{144}$ Ibid [54].
} 
This is an Accepted Manuscript of an article that will be published by Taylor \& Francis in the Journal of Media Law and it will be available at the following permanent link:

https://doi.org/10.1080/17577632.2019.1574468.

company and its sole shareholder, was also found by Warby J to be unsatisfactory and 'willing to bend the truth'.145 The judge was also evidently unimpressed by his demeanour at trial. ${ }^{146}$

The evidence therefore revealed disreputable conduct which was of a different nature from that which the defamatory imputation conveyed. However, in light of the partial justification established by the defendant in their attempt to prove insolvency, it was felt that the 'right approach'147 was to compensate FlyMeNow as a company which had 'disgracefully'148 delayed honouring its debts for several months with 'a series of dishonest excuses'149 and was teetering close to insolvency, but - and here one might suggest that we encounter a significantly sized but was not insolvent. In addition, these facts were deemed directly relevant to the context in which the defamatory statement was made 150 and suggested that the claimant was undeserving of a sum which would appear to the outside world to represent substantial vindication of its business reputation. ${ }^{151}$ All these factors had the effect of considerably reducing what would otherwise have been an award of general damages in the modest five figure range. ${ }^{152}$

The conclusions in Joseph and FlyMeNow present some similarities with the older case of the wellknown premiership goalkeeper, Bruce Grobbelaar, who was ultimately awarded the derisory sum of $£ 1$ and ordered to pay the defendant's costs, even though he succeeded in his claim over a series of reports in the Sun newspaper alleging that he had accepted bribes to let in goals on the pitch. 153 The House of Lords reinstated the jury's verdict on liability in favour of the ex-footballer, but in recognition of the unquestionable fact that he had systematically conspired to attempt to fix matches in return for bribes, it held that it would have been an 'affront to sport, public justice and public policy,'154 if a court of law had awarded substantial damages to a man who had so flagrantly breached his legal and moral obligations. 155 The claimant was shown to have behaved in a way which any right-thinking person would have unequivocally condemned. His dishonest bargains disentitled him to substantial libel damages on the basis that the value of his reputation was diminished by his own conduct.156 Grobbelaar is often cited as an example whereby contemptuous damages were awarded. Interestingly, however, nowhere in the House of Lords judgment is this term employed. Instead, the terms 'nominal'157 and 'derisory'158 are used interchangeably throughout (though the latter in much less frequency) without a firm distinction in application. Nevertheless, the divergence in terminology in this case did not actually reflect any fundamental differences of approach. Hence, it can be said that these were in effect nominal damages. 159

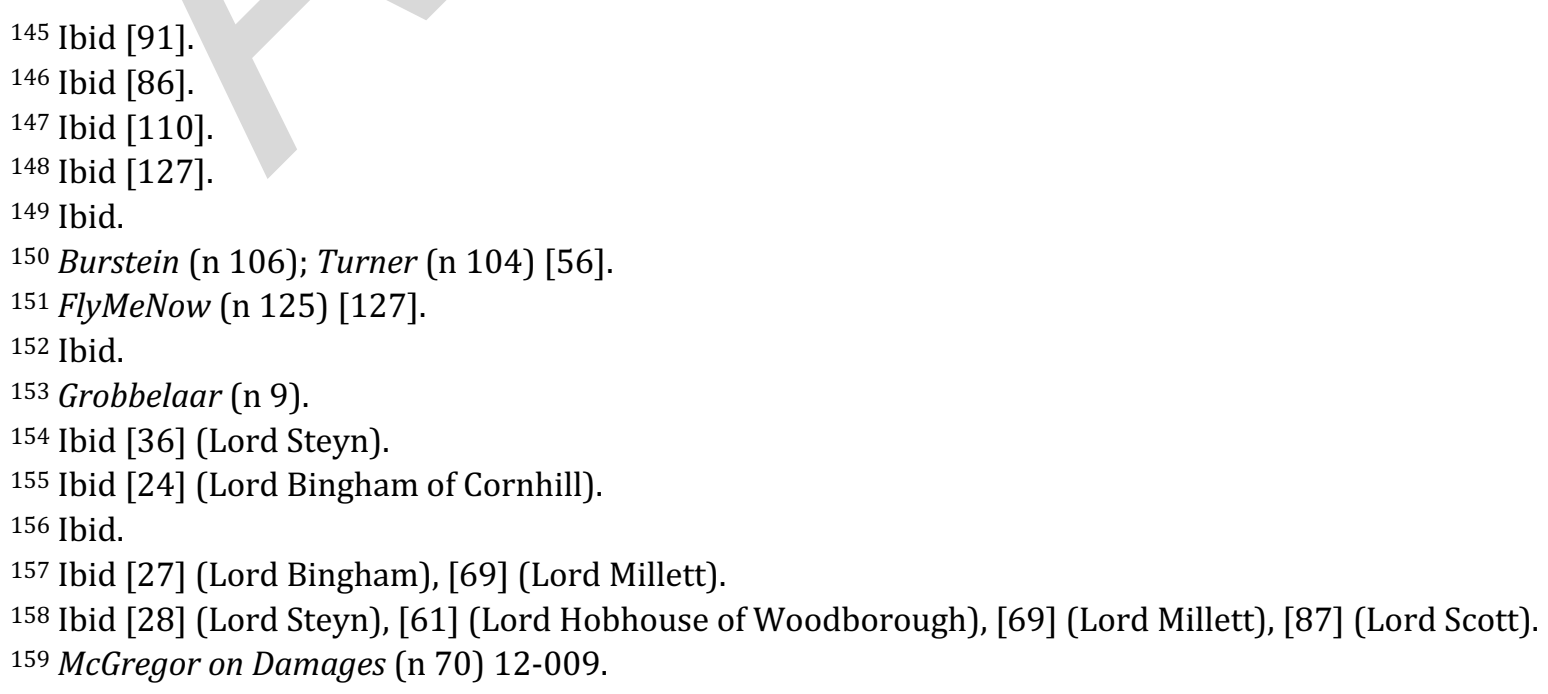


This is an Accepted Manuscript of an article that will be published by Taylor \& Francis in the Journal of Media Law and it will be available at the following permanent link:

https://doi.org/10.1080/17577632.2019.1574468.

\section{A different path forged for libel}

Libel courts' approach in relation to decreasing the award of claimants who have misconducted themselves can be contrasted with that adopted by the courts in other tortious actions. In Fairclough Homes Ltd $v$ Summers, 160 the Supreme Court recently considered the question of whether a claimant who dishonestly exaggerated on a large scale an otherwise valid personal injury claim should lose his right to damages. The court accepted that there was jurisdiction to strike out such a claim, ${ }^{161}$ at any stage of the proceedings, even after a proper assessment of liability and quantum had been made. 162 However, this draconian step should only be taken as a last resort in 'very exceptional'163 circumstances, where it is just and proportionate to strike out an action after trial, e.g. where there has been 'a massive attempt to deceive the court but the award of damages would be very small'.164 In the ordinary way, the court added, a judge would be expected to penalise the dishonest and fraudulent claimant in costs. ${ }^{165}$ Although this test provides little clarity as to the circumstances under which this power might be exercised, the consequence in Summers was that the claimant's misconduct did not lead to a reduction in damages. Quite the contrary, the claimant was held to be entitled to the award originally assessed by the judge. It has been also held that defamation is an assault on reputation analogous to a physical assault on the person. ${ }^{166}$ With this thought in mind, the Court of Appeal authority in Lane $v$ Holloway can be mobilised to support the proposition that a claimant's questionable conduct cannot reduce the real damage suffered by him or her. It was concluded that the turpitude of the claimant's conduct towards the defendant did not preclude the recovery of compensatory damages claimed for assault (though this could prevent or reduce any award of exemplary damages). The provocation by the claimant wiped out any element of aggravation but it did not reduce the real damage suffered by him. ${ }^{167}$

It is not clear what might account for the different approach adopted in Joseph and FlyMeNow. In the former, the proposition that the claimant abused the process of the court justified, in the opinion of the court, nominal damages. However, nominal damages are typically awarded, as discussed earlier, where a claimant succeeded on liability but failed to show any real damage. No authority was cited by the court in support of such an award as a suitable response to abusing the court's process. In FlyMeNow, Warby J dismissed the defendant's argument that the claim for damages was an abuse. The company had not deliberately procured a defamatory allegation to bring an action in relation to it. It rightfully brought a claim to compensate for the probable financial impact of any reputational harm and vindicate its reputation of a false imputation of

\footnotetext{
160 Summers (n 8).

161 The court also has the power under CPR 3.4(2) to strike out a claim as an abuse of process, i.e. using the legal procedure 'for a purpose or in a way which is significantly different from its ordinary and proper use'; see Att Gen v Paul Evan John Barker [2000] 1 FLR 759, [19] (Lord Bingham of Cornhill).

162 An example of proceedings constituting an abuse of process in the context of libel could include frivolous or vexatious defamation proceedings where the costs of the litigation would be disproportionate to the benefit accrued by a claimant.

163 Summers (n 8) [61] (Lord Clarke).

164 Ibid [49] (Lord Clarke).

165 Ibid [53] (Lord Clarke).

166 Attorney-General v Newspaper Publishing Plc and Ors [1988] Ch 333, 371.

167 [1968] 1 QB 379. For an interesting example from a different common law jurisdiction, see Fontin $v$ Katapodis [1962] HCA 63, in which the High Court of Australia held that the claimant's own conduct should not be considered where damages are awarded purely by way of compensation.
} 
This is an Accepted Manuscript of an article that will be published by Taylor \& Francis in the Journal of Media Law and it will be available at the following permanent link:

https://doi.org/10.1080/17577632.2019.1574468.

insolvency. The judge found that the allegation of insolvency, which was the sting of the libel in this case, was 'a material inaccuracy'168 and the defendants failed to establish that insolvency was the reason why they had not been paid. FlyMeNow could have paid but chose not to, because of the policies they had adopted. Moreover, Warby J stressed that 'the spreading of false imputations of insolvency is contrary to the public interest' 169 and underlined the 'obvious dangers' 170 of indiscriminate publication of credit information by those in business who have had bad experiences with others.

It is perhaps fanciful to suppose that Mr Grobbelaar had a reputation that was capable of being vindicated in the proceedings. In his case, the award of nominal damages was made because he had no reputation capable of suffering real damage by reason of the alleged libel, or at least none for which a just or proportionate compensation could be provided. In Joseph though, it was not suggested that the claimants' reputation no longer deserved legal protection. And in FlyMeNow, it was not suggested that the claimant company had no reputation which could be marred either. The Gillettes' reputation was actually injured by 'serious allegations' ${ }^{\prime} 171$ which entitled them to the relief sought. In a similar vein, FlyMeNow successfully established that 'significant reputational harm resulted from the defendant's email, and no doubt that was reflected in financial harm'.172 The company's goodwill, i.e. its ability to attract custom, ${ }^{173}$ might have also been injured. ${ }^{174}$ The finding that a company which was falsely accused of being insolvent had its damages reduced to a derisory level, partly because it had unreasonably delayed payments of some of its debts, fits somewhat uncomfortably with pre-existing authority that the law has always taken a 'grave

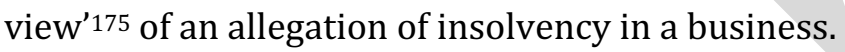

Thus, in light of the injuries inflicted on the claimants' standing and the fact that neither of the actions in Joseph and FlyMeNow were struck out, some doubt can be fairly harboured with respect to the courts' decisions to deprive claimants of suitable compensatory awards. In Fairclough, the Supreme Court refused to reduce the claimant's general damages notwithstanding the deliberate, gross and dishonest exaggeration of his claim. It is not, therefore, immediately apparent why a libel court can reduce a dishonest claimant's award, especially since there are other ways with which the courts can indicate their disapproval and disincentivise vexatious claimants (e.g. penalising a party in costs).

This variation in approach may, however, be explained by the strong nature of defamation as a vindicatory, actionable per se tort, i.e. for which any infringement of protected interests is automatically wrongful. ${ }^{176} \mathrm{~A}$ court's inquiry in such cases places greater emphasis on whether the claimant's interests have been interfered with. In making provision for a substantive damages award in the absence of factual loss, the law performs an overarching vindicatory role 'dealing

\footnotetext{
168 FlyMeNow (n 125) [132].

169 Ibid [119].

170 Ibid.

171 Joseph (n 124) [169].

172 FlyMeNow (n 125) [126].

173 IRC v Muller \& Co Margarine Ltd [1901] AC 217.

${ }^{174}$ Lewis v Daily Telegraph [1964] AC 234.

175 Kiam v Neil (No 2) [1996] EMLR 493 (CA), 509 (Beldam LJ).

176 Jameel (n 42) [91] (Lord Hoffman); Jason Varuhas, 'A Tort-Based Approach to Damages under the HRA 1998' (2009) 72(5) MLR 750, 766.
} 
This is an Accepted Manuscript of an article that will be published by Taylor \& Francis in the Journal of Media Law and it will be available at the following permanent link:

https://doi.org/10.1080/17577632.2019.1574468.

with a grievance, affirming respect for rights.' ${ }^{177}$ By contrast, a personal injury claim, which was the subject-matter in Summers, evinces a primary focus on compensation for negligently caused factual harm. This is not to suggest that negligence does not offer legal protection to certain interests, like physical well-being. This function is, however, indirectly served and does not constitute the central aim of the tort, which is to ensure compensation for the losses proximately resulting from the defendant's negligent actions. ${ }^{178}$ Put differently, in contrast to the tort of defamation, negligence is more defendant- than rights-holder-oriented, with the courts' relative focus being firmly placed on the duties and responsibilities of the defendant, rather than the claimant's interests. ${ }^{179}$ Consequently, it may be thought to be justifiable in an action for libel to regard the interests of a claimant with a past unsavoury conduct, including the conduct of their case at trial, as less deserving of damages that would be awarded to a claimant of a previously unsullied reputation. From this perspective, Joseph and FlyMeNow are important decisions also because they demonstrate the adaptability of the Burstein and Turner principles and implicitly cement the courts' willingness to recognise that 'the nature of reputation is irreparably bound up with moral judgments and questions of what is relevant to reputation cannot really be decided in a moral vacuum'.180

It appears therefore that despite a finding in the claimants' favour, their perceived misconduct can disentitle them from receiving a wholly undeserved award of damages, especially where their discreditable behaviour constitutes directly relevant background evidence or where they have behaved dishonestly and disreputably before and during litigation. The conduct of litigation is seen as irrelevant to the issue of truth and in judicial minds, the vindication of their reputation had been given in the reasons for their judgments, with no further vindication of their rights being deemed necessary. In other words, claimants were obliged to feel content with the meagre solace that could be derived from the courts' judgment on liability. However, the recovery of nominal damages raises questions as to whether claimants under those circumstances have effectively won their action in clearing their name, and crucially, how far a judge sitting alone can reduce an award because of the vindicatory effect of their carefully reasoned judgment. Given the scarcity of jury trials in libel actions in the post 2013 Act climate, this matter is likely to arise where the judge who gives a judgment in the claimant's favour also assesses the damages. If tarnishing someone's reputation alters others' perception of that person, it is appropriate to also consider whether vindication can take a material form in an award of monetary damages and the importance of this issue for libel law, with its heavy emphasis on the community's interest in knowing the truth of a defamatory charge.

\footnotetext{
177 Tony Weir, A Casebook on Tort (10th ed, Sweet \& Maxwell 2004) 7; Varuhas (n 5) 275.

178 Kenneth Abraham, The Forms and Functions of Tort Law (4th ed, West Academic Press 2012) 241.

179 Varuhas (n 176) 765-766.

180 Thomas Gibbons, 'Using evidence of discreditable behaviour to mitigate libel damages' (2006) 11(2)

CommsL 60, 61. For a discussion on the links of reputation to moral judgments and evaluations of the behaviour of others, see Dan Sperber and Nicolas Baumard, 'Moral Reputation: An Evolutionary and Cognitive Perspective' (2012) 27(5) Mind and Language 495.
} 
This is an Accepted Manuscript of an article that will be published by Taylor \& Francis in the Journal of Media Law and it will be available at the following permanent link:

https://doi.org/10.1080/17577632.2019.1574468.

\section{Libel damages, vindication and the claimant's perception in the eyes of others}

The function of damages in vindicating a claimant's reputation was well explained in Broome $v$ Cassell. ${ }^{181}$ Where damages for loss of reputation are involved,

not merely can [a claimant] recover the estimated sum of his past and future losses, but, in case the libel, driven underground, emerges from its lurking place at some future date, he must be able to point to a sum awarded by a jury sufficient to convince a bystander of the baselessness of the charge. ${ }^{182}$

The House of Lords emphasised here the perception of the ordinary and fair-minded members of society as an intrinsic part of the legal claim of defamation and relevant to the presumed damage.183 This is what makes, in part, defamation 'a distinctively sociological tort'.184 Consequently, the distinct vindicatory component of libel damages is, or should be, concerned with restoring the relationship between the claimant and the community, so that no further harm arises from the defamatory publication. By contrast, vindication in the context of other wrongs, e.g. nuisance, is concerned primarily with the reaffirmation of a claimant's right, rather than with the effect of the remedy on third parties. 185

It is questionable whether a public declaration alone that a claimant was wronged will always provide full or sufficient vindication that the claimant requires. Damages play a greater role in the common law than in other systems ${ }^{186}$ and are an important aspect of obtaining vindication. They articulate the value of an injury to the claimant's reputation, ${ }^{187}$ calibrated to take into account the circumstances of the interested parties in a specific context. Although an award of damages for defamation may not be the most efficacious remedy available, ${ }^{188}$ the public perception of a just outcome in a libel dispute is likely to be influenced, even indirectly, by knowledge of the level of compensation received. The quantitative judgment on the pound scale is deeply intertwined with the qualitative sentiment of gravity of the defendant's tortious conduct, the damage caused by it and a feeling of vindication; in other words, it is 'an outward and visible sign'189 that the law was on the claimant's side. Judges' idiosyncratic intuition that a reasoned judgment constitutes itself sufficient vindication and can relieve the implications of a libel is based on a supposition which may be unfounded. It arguably ignores the realities of the way in which libel awards actually impact on ordinary people's perception of a successful claimant. Lay observers are most likely to access a stripped-down version of a judgment through secondary sources rather than read a detailed version of it thoroughly and attentively.

\footnotetext{
181 Broome (n 16).

182 Ibid 1071 (Lord Hailsham).

183 Tolley v Fry \& Sons Ltd [1931] All ER 131; Morgan v Odhams Press Ltd [1971] 1 WLR 1239; Norman v

Future Publishing [1991] EMLR 325.

184 Several authorities stress that reputation refers to the esteem in which a person is held in society; see Plato Films Ltd v Speidel [1961] 1 AC 1090, 1137-9 (Lord Denning), Rantzen (n 17) 695-696 (Neill LJ), McCarey (n 42) 105 (Pearson LJ); see also Jerome Skolnick, 'The Sociological Tort of Defamation' (1986) 74(3) California Law Review 677.

185 Witzleb and Carroll (n 54) 34-35.

186 Report of Committee on Defamation (n 100) paras 623-624.

187 John (n 1) 607 (Sir Thomas Bingham MR).

188 See Rolph (n 26) 297, 299.

189 Cleese v Clark [2003] EWHC 137, [37] (Eady J); Farrall (n 37).
} 
This is an Accepted Manuscript of an article that will be published by Taylor \& Francis in the Journal of Media Law and it will be available at the following permanent link:

https://doi.org/10.1080/17577632.2019.1574468.

In the 1964 case of Dingle, Lord Morton remarked, and the rest of their Lordships agreed, that a judge cannot tell how widely his judgment will be reported and read; nor can he tell how far the claimant's general reputation will be improved by condemning the defendant or even expressing a favourable opinion of the claimant. ${ }^{190}$ More recent authorities are consistent with this position. In Cairns v Modi, which concerned a defamatory tweet alleging that a world-famous cricketer had been removed from the Indian Premier League auction list 'due to his past record of match-fixing', the Lord Chief Justice stated that most people would be 'rather more interested'191 in finding out the sum awarded by the court to the claimant:

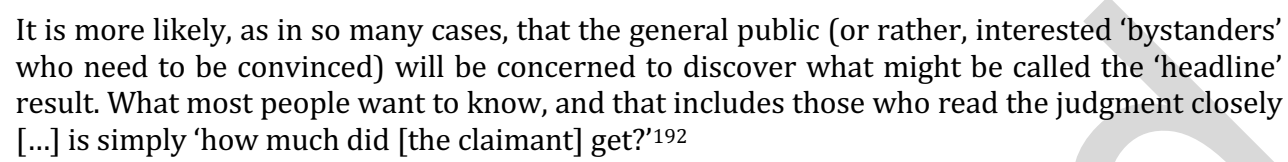

The same position was approved in later cases, such as Cruddas, where the courts acknowledged with unvarnished honesty that express elements of vindication in a judgment are 'unlikely to achieve very much in themselves' 193 and were mindful to award enough to convince any fairminded observer of the baselessness of the serious allegations advanced. ${ }^{194}$ Also, in Rai, ${ }^{195}$ where a member of the congregation of a Sikh temple was awarded $£ 50,000$ in damages following the defendant's failure to justify allegations of stealing from the temple's collection box, HHJ Parkes QC attached little weight to the impact of the reasoned judgment of the court: although there might have been some reporting of it in the local press, this was not a case where most people were likely to read a detailed analysis of the court's judgment.

This approach supports the proposition that a higher libel award in favour of a claimant is perhaps more likely to be perceived as a demonstrable restoration of a positive public image than a lower award. It is therefore not a great leap of logic to suggest that there is a strong possibility that an award of some magnitude holds greater restorative power. ${ }^{196}$ And vice versa, a lower award will do little to rebut the public perception that the reputational damage complained of was as serious as originally asserted. However, the wider applicability of this proposition remains open to empirical enquiry which could determine whether ordinary, reasonable publishees in fact associate the size of damages awards with repaired reputations.

In Grobbelaar, Joseph and FlyMeNow, the need for vindication was exhausted by the reasoned judgments, thereby eliminating the claimants' compensation. Pondering the reasoning in cases like Cairns, Cruddas and Rai, we are however led to a rather paradoxical position, which very much calls into question the vindicatory effects of a reasoned judgment alone that judges themselves have readily endorsed. While the judgments made by impartial arbiters of the disputes go some distance to vindicate the claimants' reputation, they essentially provide only some semblance of vindication and remain symbolically significant. The recovery of nominal

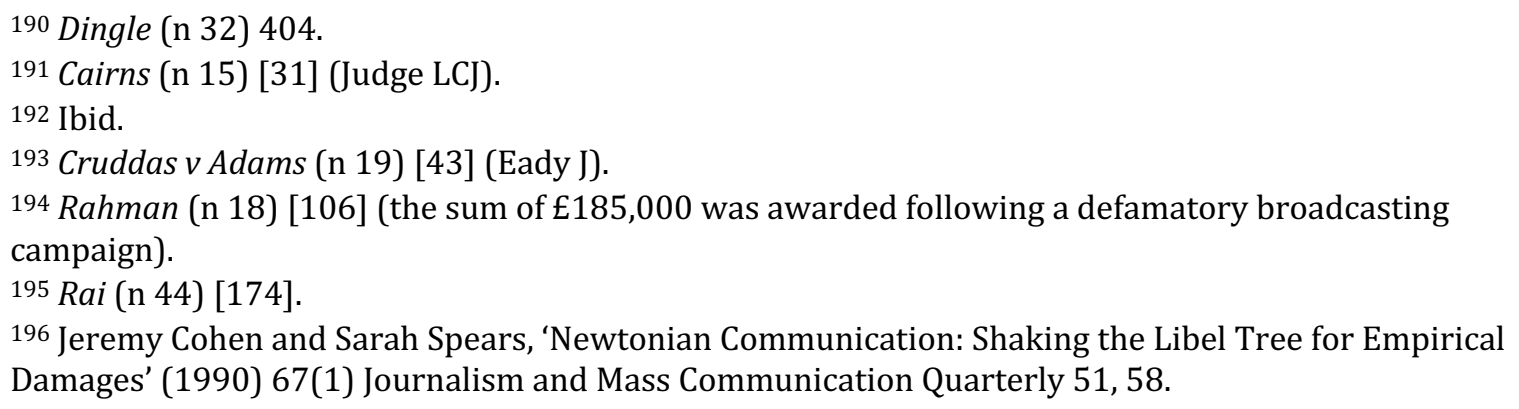


This is an Accepted Manuscript of an article that will be published by Taylor \& Francis in the Journal of Media Law and it will be available at the following permanent link:

https://doi.org/10.1080/17577632.2019.1574468.

damages for a properly pleaded tortious interference in this context cannot be neatly harmonised or reconciled with the strong restorative and vindicatory policy that underpins libel damages. The claimants in Joseph and FlyMeNow effectively lost their action to destigmatise their names and re-establish their standing in their respective communities. Notably, in Joseph, the court determined costs in the defendants' favour, despite the claimants' success on liability. ${ }^{197}$ Any modicum of success in the proceedings was thus over-clouded by a negative cost order against The Gillettes, thereby depriving them of any sense of vindication.

To be analytically provocative, it is worth deliberating on the existence of alternative 'weapons' in a libel court's armoury that could be deployed by judges to express their discontent with claimants' dishonest conduct, instead of depriving them of an award of substantial damages. As Lord Reed remarked in his 2012 speech 'Lies, damned lies',

A finding at [the conclusion of the trial] that a document was forged or suppressed, or that a party told lies in his evidence, is part of the court's ordinary adjudicative function. The judge may decide to punish the party for contempt, or refer the case to the prosecuting authorities, [or penalise a party in relation to expenses or in its award of interest], but he or she will nevertheless have adjudicated on the dispute. ${ }^{198}$

Contempt proceedings may be brought against a person if he or she makes, or causes to be made, a false statement in a document verified by a statement of truth without an honest belief in its truth. ${ }^{199}$ Early in 2018, for example, an NHS trust successfully brought contempt proceedings against a disk jockey who pursued a fraudulent claim for clinical negligence damages by dishonestly exaggerating the continuing symptoms and disabling effects of comparatively minor injuries which had been negligently treated.200 Although proceedings for contempt of court are evidently considered as effective sanctions by the courts, 201 it is quite uncertain how far claimants bringing dishonest claims are in fact deterred by the possibility that they may end up with a prison sentence, if exposed. Such proceedings may only be brought by the Attorney General or with the permission of the court. ${ }^{202}$ From a practitioner's perspective, 'the idea that the Attorney General might ever get round to taking his Fiat out of the governmental garage is contradicted by experience.'203 It may also be unrealistic to anticipate that the cheated party will vigorously protect the court's public process by pursuing a private prosecution. ${ }^{204}$ Also, even if the trial judge hears both the permission to bring contempt proceedings and the proceedings themselves provided a permission is granted - additional private or public expenses are likely to be accumulated at the end, including the public expenditure incurred from the cost of a prison place if a conviction leads to imprisonment. ${ }^{205}$ Thus, penalising a claimant as a contemnor, or referring

197 Joseph v Spiller (Costs) [2012] EWHC 3278.

198 Lord Reed, 'Lies, Damned Lies' (n 3) 2.

199 CPR 32.14(1).

200 Calderdale and Huddersfield NHS Foundation Trust v Atwal [2018] EWHC 961.

201 South Wales Fire and Rescue Service v Smith [2011] EWHC 1749, [2] - [7] (Moses LJ), endorsed by the Supreme Court in Summers (n 8) [58].

202 CPR 32.14(2).

203 William Norris, 'Look out: I've got a power, but I am not going to use it' (2012) 3 Journal of Personal Injury Law 169, 175.

204 Ibid.

205 The average annual overall cost of holding a prisoner in England and Wales is currently estimated $£ 35,371$; Ministry of Justice, Prison performance statistics 2016 to 2017 - Costs per prison place and cost per prisoner 2016 to 2017, Table 2a <https://www.gov.uk/government/statistics/prison-performancestatistics-2016-to-2017> accessed 28 June 2018. 
This is an Accepted Manuscript of an article that will be published by Taylor \& Francis in the Journal of Media Law and it will be available at the following permanent link:

https://doi.org/10.1080/17577632.2019.1574468.

the matter to the prosecuting authorities, may not be the most economical way to resolve the dispute.

Moreover, a claimant who secures nominal damages will not necessarily recover costs. The Civil Procedure Rules (CPR) give a court full power and wide discretion to determine the extent to which costs are to be paid and by whom. ${ }^{206}$ As Lord Lloyd of Berwick famously said in the House of Lords decision of Bolton MDC $v$ Secretary of State for the Environment: 'as in all questions to do with costs, the fundamental rule is that there are no rules'.207 In deciding what order to make about costs, the court is entitled to consider all the circumstances, including the manner in which the parties have pursued or defended particular allegations ${ }^{208}$ and can exercise its discretion against the successful party, if there is some reason connected with the case.209 Ordering dishonest claimants to pay costs was seen by the Supreme Court in Summers as a means to achieve effective deterrence:

\begin{abstract}
It is entirely appropriate [...] to order the claimant to pay the costs of any part of the process which have been caused by his fraud or dishonesty and moreover to do so by making orders for costs on an indemnity basis. Such cost orders may often be in substantial sums perhaps leaving the claimant out of pocket. It seems to the Court that the prospect of such orders is likely to be a real deterrent. 210
\end{abstract}

So, if a dishonest claimant succeeds and receives a small amount of damages, he or she will have presumably achieved vindication for the reputational injury, but the court's view in Summers means in practice that any damages recovered may be minimal when set against the costs of the proceedings. Consequently, claimants would probably leave the court in a less prosperous position than when they entered it. Whilst a pyrrhic and expensive victory is viewed in Summers as an essential, yet pragmatic, compromise where claimants have behaved inappropriately, it might reasonably be questioned whether this is a price worth paying in the context of libel. The cost in that case would be out of proportion to what would have been accomplished in terms of vindication. ${ }^{211}$ The alternative weapon of costs added to the court's armoury by Summers does not seem to provide a fully satisfactory solution in libel either. Hence, there might be some value in the suggestion that the serious harm threshold under s 1 could be extended by including a requirement that a case proceeds only where there is a real prospect of vindication, and that vindication, if achieved by litigation, is proportionate to the costs of the trial.212 There is therefore a case for consideration of this position in libel law.

\title{
Conclusions
}

Although the defence tactic to bring evidence of the claimant's bad reputation in mitigation of damages used to be tightly controlled by the courts, ${ }^{213}$ this practice was relaxed to some extent by Burstein. ${ }^{214}$ Since then, the English courts appear to have adopted an even more liberal and

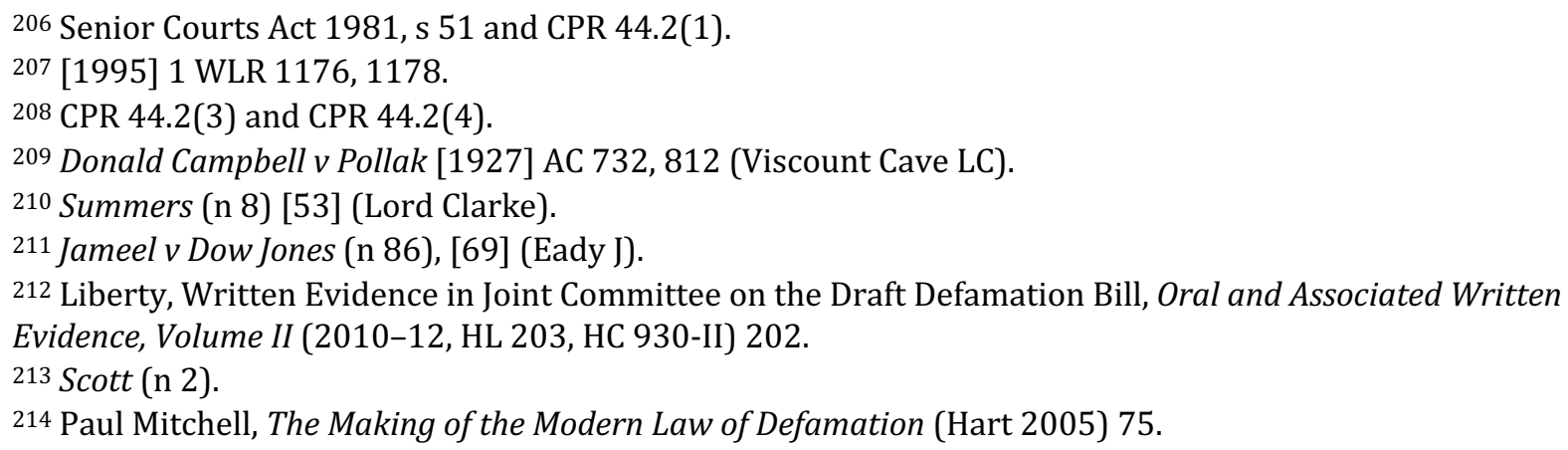


This is an Accepted Manuscript of an article that will be published by Taylor \& Francis in the Journal of Media Law and it will be available at the following permanent link:

https://doi.org/10.1080/17577632.2019.1574468.

broad-minded approach to admitting evidence of discreditable conduct on the part of the claimant - even before the time the libel was published - so long as specific acts or omissions are directly and temporally relevant to the context of publication. ${ }^{215}$ It could be suggested that the claimants' 'dishonesty' before action or 'disreputable' conduct of their case at trial may be seen as a criterion that potentially expands the breadth of the mitigating factor of 'bad reputation' or as a reiteration of this factor in another (dis)guise.

As the landscape of legal disputes around reputation continues to evolve, judges increasingly seem to be more critical in their reasoning in terms of closely examining and boldly denouncing claimants' unmeritorious practices in pursuing their claims up until the time a judgment is delivered. ${ }^{216} \mathrm{~A}$ strong message is therefore sent to parties who falsely assume that it is only the defendant's conduct that is subject to scrutiny when damages are assessed. So, a claimant's conduct up to, and including, the trial is capable of reducing damages, just as a defendant's conduct up to, and including, the proceedings can aggravate damages.

However, as the Court of Appeal observed in Burstein, 'every publication has a contextual background, even if the publication is substantially untrue'.217 If it is accepted that a claimant's unscrupulous behaviour in litigation can be considered against this background, the absence of a sufficiently reliable yardstick against which this factor can be objectively ascertained may mean that the exclusionary discretion of the court can at times be exercised with less rigidity. What constitutes dishonest or disreputable conduct, and how its gravity is to be weighed against its potential impact on the size of an appropriate award, remain unclear in this context. This undesirable element of uncertainty calls for a more coherent and workable set of factors the courts can weigh in making that determination. An unduly liberal approach in this regard might be exploited by defendants who may seek to rely on evidence of specific acts or omissions on the part of the claimant in the litigation process and needlessly distract the court from what is 'directly relevant' background context.

Whilst painstakingly and critically examining claimants' actions in the past and conduct of their case at trial is undoubtedly a well-intended judicial practice, it is questionable whether a nominal award, accompanied by a reasoned judgment in favour of a claimant who has suffered reputational damage but displayed reprehensible conduct before or during litigation, are sufficient to mark the significance of the unlawful interference with the claimant's public self. Such an approach carries with it the potential unintended consequence of eroding the vindicatory element of an award and stretches nominal damages from their historically intended function. This concern assumes even more salience against the backdrop of the new Defamation Act 2013. Considering the higher standard set by the serious harm requirement, it may reasonably be anticipated that a claimant, who has shown that the defamatory meaning is sufficiently grave to cross the serious harm threshold, is even more deserving, thus meriting an enhanced award of damages.

The ripples created by Grobbelaar and Joseph seem to have more recently found their way into FlyMeNow. However, as the discussion showed, this emerging trend in relation to diminishing a dishonest claimant's award of general damages does not maintain consistency with other tortious causes of action, thereby failing to establish a degree of coherence and predictability on the point.

215 Turner (n 104); Goody (n 101); King (n 101); Oyston (n 18).

216 Praed v Graham (1889) 24 QBD 53, 55 (Lord Esher MR); Broome (n 16) 1071 (Lord Hailsham).

${ }^{217}$ Burstein (n 106) 598. 
This is an Accepted Manuscript of an article that will be published by Taylor \& Francis in the Journal of Media Law and it will be available at the following permanent link:

https://doi.org/10.1080/17577632.2019.1574468.

The position is further complicated by the fact that there seems to be little certainty over the vindicatory power and effect of the terms of a reasoned judgment alone. On the one hand, it has been asserted, albeit with some cautious reservation, that vindication of a successful claimant's reputation can be given in the reasons for the judgment. ${ }^{218}$ But, on the other, the force of this argument is somewhat undercut by the Lord Chief Justice's surprisingly candid remarks in Cairns $v$ Modi about the extent to which a reasoned judgment can offer complete vindication, especially if it is accepted that lay observers will be less interested in closely reading a judgment and will, instead, draw their own inferences from the size of the award.

Where claimants have misconducted themselves, but injury has been caused by the words complained of, nominal awards do not truly operate fairly, especially because there is a real possibility that the public perception of their reputation has been tainted by negligible damages. Minimal awards will merely be of a trumpery character in this context and are unlikely to be wellsuited to eradicate the adverse consequence which could arise from the future disrespect the claimant might face as a result of the libellous publication that can be lasting and widespread. At least as far as personal injury cases are concerned, the Supreme Court decision in Summers indicates that there is a particularly robust appetite for exploring different sanctions against claimants' dishonesty. However, the alternative 'weapons' in the courts' arsenal, as outlined in Summers, are attended with serious corresponding disadvantages and do not offer a wholly sustainable solution in the context of libel. Whether the reasons for judgment alone can provide sufficient vindication in the circumstances of a case and form the basis for lessening the quantum of damages must remain a nuanced, fact-specific inquiry into the particularised circumstances of a case. This needs to be guided throughout by a clear and solid framework for decision-making, which embodies the attractive idea that the fundamental importance of the protected reputational interests itself may justify a substantial award to mark their infringement, so as to ensure that the vindicatory purpose and merits of libel damages are not lost sight of.

218 Purnell (n 27). 